bureaux are listed separately, the latter being institutions without libraries which have an active policy of gathering and disseminating information. The annotated lists are arranged alphabetically first for London, and then, separately, those outside London. A list of medical libraries holding periodicals registered in the World List and Union Catalogue is appended with an index of special collections and subjects.

\section{Aerial Photographs for Scientific Purposes}

From time to time aerial photographs are required for scientific purposes. Facilities for such photographs, required for non-commercial scientific purposes, may be provided by the Royal Air Force and Royal Navy, but such facilities are limited, and priority must, therefore, be allocated to the various requirements. The Advisory Committee on Airborne Research Facilities, a joint committee of the Royal Society and the Services, is to advise the Services on this matter. Requirements for photographs to be taken during 1948 should be forwarded to the Committee, at the Royal Society, Burlington House, London, W.1, before October 31,1947 ; it will assist $(a)$ if the envelope is marked 'Aerial Photographs' ; $(b)$ if grid references on the ordnance survey G.S.G.S. $I$ in. series are quoted, alternatively exact latitude and longitude; and $(c)$ if the scale required is stated. (It should be noted that cover is easier to provide in scales of $1 / 10,000$ or $1 / 25,000$.)

\section{University of Birmingham : Appointments}

THE chair of production engineering established two years ago by a munificent gift from Messrs. Joseph Lucas, Ltd., has been filled by the appointment of Dr. T. U. Matthew, director of research of the Bedaux Company for Africa, Ltd. Dr. Matthew's exceptional ability, capacity for research, experience of the technical as well as the production and administrative sides of engineering, his wide interests and scholarly mind will enable him to fill the post with distinction and success. $\mathrm{He}$ had a brilliant career at King's College, London, and in postgraduate research at Cambridge. The chair of production engineering was established "to foster through research the full development of every aspect of Production Engineering and the education through special post-graduate courses of a supply of men who possess not only a sound grasp of the fundamentals of engineering but also a specialized knowledge of production methods and processes and the varied aspects of organisation and control".

The chair of zoology has been filled by the appointment of Mr. P. B. Medawar, lecturer in zoology in the University of Oxford and a fellow of Magdalen College.

Prof. V. G. Childe, professor of prehistoric European archæology in the University of London, has been appointed Mason Lecturer for 1947-48.

\section{Commonwealth Fund Fellowships Awards}

THE Committee of Award of the Commonwealth Fund Fellowships has made the following appointments, among others, to fellowships tenable by British graduates in American universities for one year beginning September 1947: J. P. Bentley, Charing Cross Hospital Medical School and King's College, University of London, to Emory University, Atlanta, Georgia, in surgery ; M. R. Bonham Carter,
Balliol College, Oxford, to the University of Chicago, in political science; R. P. Brittain, University of Glasgow, to New York University College of Medicine, in forensic medicine; A. J. Y. Brown, University of Aberdeen, to the University of California, in economics; W. J. G. Cameron, College of Technology, Queen's University, Belfast, and Queen Mary College, University of London, to the University of Illinois, in engineering; F. J. Dyson, Trinity College, Cambridge, and Imperial College of Science and Technology, University of London, to Cornell University, in mathematics ; F. H. Holmes, University of London, to Princeton University, in chemistry; Dr. James Innes, University of Edinburgh, to Washington University, St. Louis, in medicine; D. S. Jones, Corpus Christi College, Oxford, to the Massachusetts Institute of Technology, in mathematics; Dr. I. C. Jones, University of Liverpool, to Harvard University, in zoology ; James Kenny, University of Glasgow, to Princeton University, in economics; Dr. G. A. Maw, University College, University of London, to Cornell University Medical School, in biochemistry; Bowman Scott, Imperial College of Science and Technology, University of London, to Harvard University School of Business Administration, in engineering ; Alexander Slessor, University of Glasgow, to Harvard University Medical School, in medicine; Dr. Harry Stalker, University of Edinburgh, to Cornell University Medical School, in medicine.

The following have been appointed to fellowships tenable by candidates holding appointments in the Home Civil Service: T. F. Bird, Balliol College, Oxford, and London School of Economics, University of London, of the Ministry of Civil Aviation ; C. E. Calveley, King's College, University of London, of the Post Office; J. A. R. Pimlott, Worcester College, Oxford, of the Lord President's Office; J. B. Williams, MeGill University, and Trinity College, Cambridge, of the Colonial Office (fellowship awarded in 1939).

\section{Announcements}

Aт a Congregation at the University of Cambridge on June 12, eleven honorary degrees were conferred, including that of Sc.D. on : Prof. Linus C. Pauling, professor of chemistry in the Californian Institute of Technology; Sir Edward Mellanby, secretary of the Medical Research Council; Prof. C. T. R. Wilson, emeritus professor of natural philosophy in the University of Cambridge.

Prof. V. G. CHILDE, professor of prehistoric European archæology in the University of London, has been elected a member of the Royal Netherlands Academy of Sciences of Amsterdam (Section of Letters and Historical Sciences).

The Commissioners for the Exhibition of 1851 announce the award of senior studentships for 1947 to the following: On the recommendation of the University of Cambridge : J. S. Courtney-Pratt, for research in physics at the University of Cambridge. On the recommendation of the University of Oxford : D. H. Whiffen, for research in physical chemistry at the University of Oxford ; E. M. Vaughan-Williams, for research in pharmacology at the University of Oxford. On the recommendation of the Imperial College of Science and Technology, London: Dr. K. D. Froome, for research in physics at the Imperial College of Science and Technology, London. 